\title{
Development of Physical Protection Regulations for Rosatom State Corporation Sites under the U.S.- Russian MPC\&A Program
}

Alexander Izmaylov ${ }^{1}$, Vladimir Babkin ${ }^{1}$, Nikolay Shemigon ${ }^{1}$, Patricia O'Brien ${ }^{2}$, Troy Wright ${ }^{3}$, Michael Hazel ${ }^{4}$, John Tuttle ${ }^{4}$, Mitchel Cunningham ${ }^{4}$, Melinda Lane $^{5}$, Dmitry Kovchegin ${ }^{6}$.

${ }^{1}$ Federal State Unitary Enterprise SNPO "Eleron", Moscow, Russian Federation;

${ }^{2}$ U.S. Department of Energy, Washington, DC, USA;

${ }^{3}$ Gregg Protective Services, Richland, WA, USA;

${ }^{4}$ Pacific Northwest National Laboratory, Richland, WA, USA;

${ }^{5}$ Lawrence Livermore National Laboratory, Livermore, CA, USA;

${ }^{6}$ Booz Allen Hamilton, Moscow, Russian Federation.

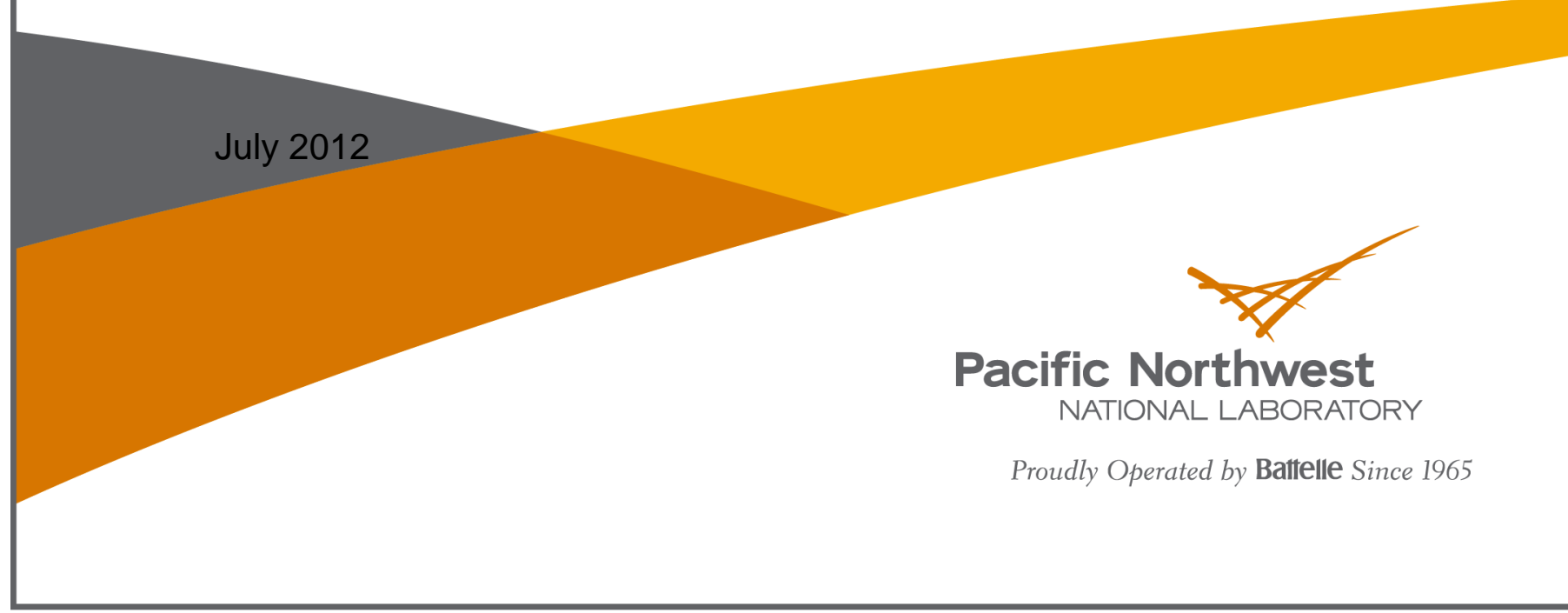




\title{
DISCLAIMER
}

This report was prepared as an account of work sponsored by an agency of the United States Government. Neither the United States Government nor any agency thereof, nor Battelle Memorial Institute, nor any of their employees, makes any warranty, express or implied, or assumes any legal liability or responsibility for the accuracy, completeness, or usefulness of any information, apparatus, product, or process disclosed, or represents that its use would not infringe privately owned rights. Reference herein to any specific commercial product, process, or service by trade name, trademark, manufacturer, or otherwise does not necessarily constitute or imply its endorsement, recommendation, or favoring by the United States Government or any agency thereof, or Battelle Memorial

Institute. The views and opinions of authors expressed herein do not necessarily state or reflect those of the United States Government or any agency thereof.

\author{
PACIFIC NORTHWEST NATIONAL LABORATORY \\ operated by \\ BATTELLE \\ for the \\ UNITED STATES DEPARTMENT OF ENERGY \\ under Contract DE-AC05-76RL01830
}

Printed in the United States of America

\author{
Available to DOE and DOE contractors from the \\ Office of Scientific and Technical Information, \\ P.O. Box 62, Oak Ridge, TN 37831-0062; \\ ph: (865) 576-8401 \\ fax: $(865) 576-5728$ \\ email: reports@adonis.osti.gov
}

Available to the public from the National Technical Information Service, U.S. Department of Commerce, 5285 Port Royal Rd., Springfield, VA 22161

ph: (800) 553-6847

fax: $(703) 605-6900$

email: orders@ntis.fedworld.gov

online ordering: http://www.ntis.gov/ordering.htm 


\section{Development of Physical Protection Regulations for Rosatom State Corporation Sites under the U.S.- Russian MPC\&A Program}

Alexander Izmaylov ${ }^{1}$, Vladimir Babkin ${ }^{1}$, Nikolay Shemigon ${ }^{1}$, Patricia O'Brien $^{2}$, Troy Wright ${ }^{3}$, Michael Hazel ${ }^{4}$, John Tuttle ${ }^{4}$, Mitchel Cunningham ${ }^{4}$, Melinda Lane ${ }^{5}$, Dmitry Kovchegin ${ }^{6}$

${ }^{1}$ Federal State Unitary Enterprise SNPO “Eleron”, Moscow, Russian Federation;

${ }^{2}$ U.S. Department of Energy, Washington, DC, USA;

${ }^{3}$ Gregg Protective Services, Richland, WA, USA;

${ }^{4}$ Pacific Northwest National Laboratory, Richland, WA, USA;

${ }^{5}$ Lawrence Livermore National Laboratory, Livermore, CA, USA;

${ }^{6}$ Booz Allen Hamilton, Moscow, Russian Federation.

July 2012

Prepared for the U.S. Department of Energy

under Contract DE-AC05-76RL01830

Pacific Northwest National Laboratory

Richland, Washington 99352 
PNNL-21418

\section{Table of Contents}

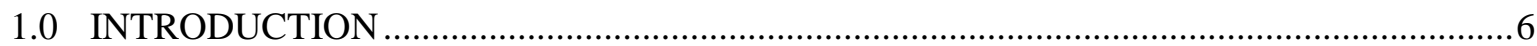

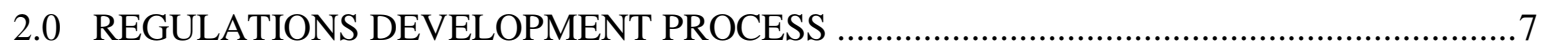

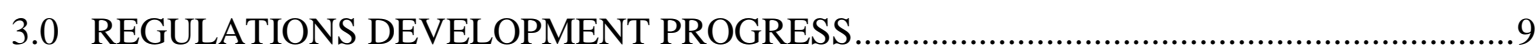

4.0 U.S.-RUSSIAN ACTIVITIES TO RECONCILE ISSUES RELATED TO DOCUMENT CONTENT AND IDENTIFY GAPS FOR FUTURE REGULATIONS DEVELOPMENT ...12

5.0 FUTURE REGULATORY DEVELOPMENT ACTIVITIES .............................................. 14

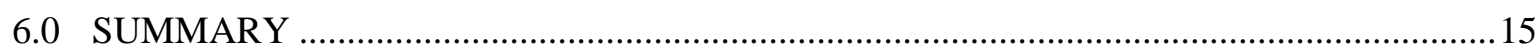

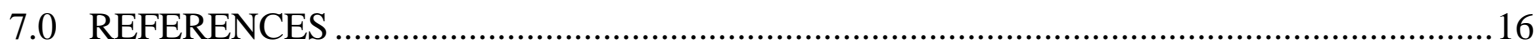




\section{ABSTRACT}

This paper describes issues related to upgrading the physical protection regulatory basis for Rosatom State Corporation sites. It is underlined that most of the regulatory and methodological documents for this subject area have been developed under the U.S.-Russian Material Protection, Control and Accounting (MPC\&A) Program. According to the joint management plan developed and agreed upon by the parties in 2005, nearly 50 physical protection documents were identified to be developed, approved and implemented at Rosatom sites by 2012. It is also noted that, on the whole, the plans have been fulfilled. The documents cover all stages of the Physical Protection System (PPS) lifecycle: pre-design stage (vulnerability analysis, concept design), detailed design, PPS commissioning and operation. Additionally, a number of regulatory documents in the area of managerial issues, training personnel responsible for physical protection, protective forces, etc. have been developed. The documents in development are continuously discussed and improved due to the quarterly meetings of the U.S.-Russian Joint Working Group and special workshops (for example, a workshop on PPS effectiveness assessment). This paper briefly characterizes the approved agency level regulatory and methodological documents and describes new approaches to their development (model inter-agency documents, etc.). Based on the materials featured in this paper, a conclusion can be made on substantial progress in the area of the development of physical protection regulatory documents as one of the factors influencing a level of nuclear material and nuclear facility physical protection. This paper examines suggestions for the development of new regulations and the update of obsolete ones, which will result in a further increase of the Rosatom site PPS effectiveness. 
PNNL-21418

\subsection{INTRODUCTION}

Regulations are one of the key foundations of sustainable operation of physical protection systems. Well-developed regulations ensure that all organizations and individuals involved in physical protection (PP) activities know the goals of their work, the mandatory requirements critical for PPS operations at nuclear sites, and the best ways to ensure compliance with these requirements. When properly implemented, a specific nuclear regulation ensures that all activities are performed in a uniform manner and serves as a basis for training nuclear security personnel and evaluating the status of PPS.

Rosatom State Corporation pays significant attention to the development of regulatory documents, including those related to physical protection of Russian nuclear sites. The regulatory basis is continuously improved through development of new regulations and revision of regulations issued earlier. New regulations take into account international documents issued by the International Atomic Energy agency (IAEA) [1, 2] and key national federal level regulations [3, 4].

The U.S. Department of Energy, through the MPC\&A Regulatory Development Project (RDP), has been supporting Rosatom in developing PP regulations since 1999. This work includes joint identification of regulatory gaps, best practice exchanges necessary to achieve mutual understanding of the content of future regulations, development of new regulations and revision of regulations developed earlier based on feedback from the implementation process at Russian nuclear sites. A previous status report on joint regulation development activities was provided at INMM in 2009 [5]. Since then, thirteen PP regulations have been developed and enacted. This paper provides a report on progress achieved since that time and outlines future regulatory development plans. 


\subsection{REGULATIONS DEVELOPMENT PROCESS}

The first long-term Regulations Development Plan was agreed and adopted by the U.S. and Russian sides in 2005. In addition, a project management approach was adopted aimed at tracking plan implementation and maintaining the plan, including introduction of justified and mutually agreed changes. This plan was most recently reviewed and updated in 2011-2012.

Specific regulations are developed as part of the contract between Pacific Northwest National Laboratory and one of the Russian organizations involved in PP activities. Key Russian organizations involved in this process are Eleron, Atomzaschitainform, Atomguard and Interdepartmental Special Training Center (ISTC). The organization awarded with a contract establishes a working group that consists of its own experts, representatives of Rosatom, representatives of Rosatom nuclear facilities and other experts. The working group develops a work plan, drafts the regulation and works with outside reviewers to collect feedback and reflect it in the regulation. Key stages of the regulation development process are provided in Figure 1.

\section{Figure 1: Key stages of regulatory development process are drafting, review, and enactment}

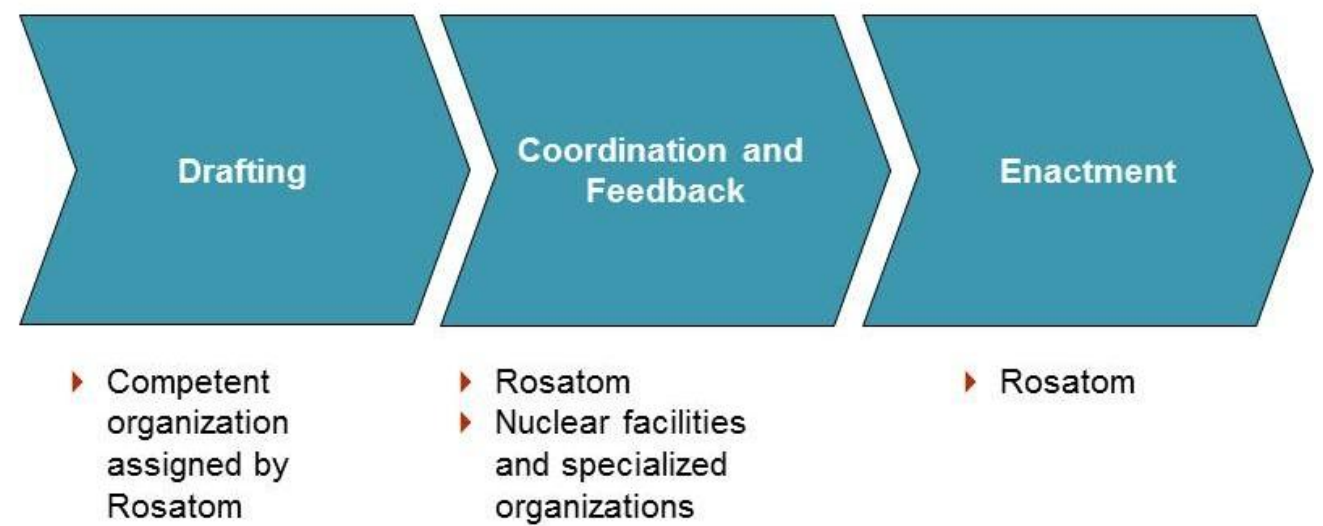

A key part of the regulation development process is reconciliation with all stakeholders. Each deliverable is sent for review to Rosatom and the U.S. subject matter experts. Certain sections of draft regulations are not shared with the U.S. side based on information sensitivity considerations; however, parties manage to maintain a significant level of openness sufficient to allow U.S. experts to provide meaningful review and feedback. Additionally, each draft is sent for review to nuclear facilities and specialized organizations that will be in charge of implementing the developed regulation. Until critical comments for each deliverable are resolved, the working group cannot proceed with development of the regulation.

After all comments are reconciled, the regulation is sent for enactment to Rosatom Headquarters. Enactment involves additional review by legal and financial departments if needed and departments in charge of specific facilities, e.g. nuclear fuel cycle, nuclear power plants, research institutions. 
PNNL-21418

Regulations are typically signed by the senior Rosatom official - Director or Deputy Director - and then distributed to implementing organizations. 


\subsection{REGULATIONS DEVELOPMENT PROGRESS}

Since the last progress report was provided in 2009, thirteen new or revised PP regulations have been enacted covering all stages of PPS lifecycle, including pre-design, design, commissioning and operation. Table 1 provides a list of main enacted regulations.

Table 1. Physical protection regulations developed under MPC\&A Program and enacted by Rosatom in 2009-2011

\begin{tabular}{|c|c|}
\hline Title & Enactmen \\
\hline $\begin{array}{l}\text { Set of Model Forms to be Generated in Relation to the Operation of } \\
\text { PPS and Recommendations for Completion of Forms }\end{array}$ & 2009 \\
\hline $\begin{array}{l}\text { Methodological Recommendations for Collecting, Processing, and } \\
\text { Submitting Information to Government Corporation Rosatom Regarding } \\
\text { the Physical Protection System Components at Nuclear Sites }\end{array}$ & 2009 \\
\hline Model Plans and Methods for Comprehensive Testing of PP Equipment & 2009 \\
\hline $\begin{array}{l}\text { Procedures for the Turnover of Physical Protection and Security } \\
\text { Equipment to Security Forces }\end{array}$ & 2009 \\
\hline $\begin{array}{l}\text { Instructional Guidelines for Preparation of Statements of Work for the } \\
\text { Creation (Modernization) of Physical Protection Systems at Nuclear } \\
\text { Facilities }\end{array}$ & 2009 \\
\hline $\begin{array}{l}\text { Methodological Instructions for Organizing and Conducting Initial and } \\
\text { Advanced Training in the Area of Nuclear Material Protection, Control, and } \\
\text { Accounting for Personnel at Organizations of Rosatom State Corporation }\end{array}$ & 2009 \\
\hline $\begin{array}{l}\text { Methodological Recommendations for Physical Protection Equipment } \\
\text { Scheduled Maintenance Procedures }\end{array}$ & 2010 \\
\hline $\begin{array}{l}\text { Standard (Model) Duties of Physical Protection Personnel (A Set of } \\
\text { Document for Various Job Categories) }\end{array}$ & 2010 \\
\hline $\begin{array}{l}\text { Methodological recommendations on the site's planning for ensuring } \\
\text { NM PP and upgrading its PP system }\end{array}$ & 2011 \\
\hline Methodological Recommendations for Collection, Processing,and & 2011 \\
\hline
\end{tabular}




\begin{tabular}{|l|l|}
\hline Distribution of Information on Physical Protection Equipment Reliability & \\
\hline $\begin{array}{c}\text { A Model Manual on System Administration of Automated Physical } \\
\text { Protection Systems }\end{array}$ & 2011 \\
\hline $\begin{array}{l}\text { Model Regulation (instruction) on the Organization of Activities at } \\
\text { Physical Protection System Alarm Stations }\end{array}$ & 2011 \\
\hline $\begin{array}{l}\text { Set of Rosatom Standard (Model) Forms for Site Level Documents To } \\
\text { Be Prepared by the Nuclear Site in Order to Satisfy the Requirements of } \\
\text { Federal level Document «Rules of Physical Protection of Nuclear Material, } \\
\text { Nuclear Facilities, and Nuclear Material Storage Points» }\end{array}$ & 2011 \\
\hline
\end{tabular}

Russian nuclear facilities have already gained significant experience implementing these regulations. Feedback obtained through the agency monitoring process and other channels is used during ongoing regulations development activities and incorporated in the revised or newly developed regulations. Table 2 provides a list of regulations under development this time (2012).

Table 2. Physical protection regulations under development now in the scope of MPC\&A Program

\begin{tabular}{|c|c|}
\hline Title & Remarks \\
\hline Methodological Recommendations for Vulnerability Analysis & $\begin{array}{c}\text { Enactment } \\
\text { Process }\end{array}$ \\
\hline $\begin{array}{c}\text { Methodological Recommendations for Effectiveness } \\
\text { Assessment of Nuclear Facilities Physical Protection }\end{array}$ & Revision \\
\hline $\begin{array}{c}\text { Procedures for establishing (upgrading) physical protection } \\
\text { systems at nuclear facilities }\end{array}$ & New \\
\hline $\begin{array}{c}\text { Methodological Recommendations for Effectiveness } \\
\text { Facilties during Transportation }\end{array}$ & New \\
\hline $\begin{array}{c}\text { Methodological Recommendations for Organizing Physical } \\
\text { Protection System Operation }\end{array}$ & New \\
\hline $\begin{array}{c}\text { Procedures for Developing and Implementing } \\
\text { Compensatory Administrative and Technical Measures }\end{array}$ & New \\
\hline \begin{tabular}{l} 
Methodological Recommendations for the Conceptual \\
\hline
\end{tabular} & Revision \\
\hline
\end{tabular}


PNNL-21418

\begin{tabular}{|l|l|}
\hline Design of Physical Protection Systems & \\
\hline $\begin{array}{c}\text { Methodological Recommendations on Selection and Use of } \\
\text { Explosive and Metal Detectors in PPS }\end{array}$ & New \\
\hline $\begin{array}{c}\text { Methodological Recommendations for the Categorization of } \\
\text { Objects of Physical Protection and Nuclear Sites }\end{array}$ & Revision \\
\hline $\begin{array}{l}\text { Methodological Recommendations for Commissioning a } \\
\text { Physical Protection System }\end{array}$ & Revision \\
\hline
\end{tabular}




\subsection{U.S.-RUSSIAN ACTIVITIES TO RECONCILE ISSUES RELATED TO DOCUMENT CONTENT AND IDENTIFY GAPS FOR FUTURE REGULATIONS DEVELOPMENT}

In addition to regulations development itself, the Regulatory Development Project supports a number of other activities. These activities include workshops to exchange best practices on the issues related to physical protection and reconcile issues related to content of the documents under development (supported jointly with Sustainability Project) and ongoing crosswalk analysis of regulatory documents coverage.

In recent years workshops covering the following issues were conducted:

- PPS Vulnerability Analysis and Effectiveness Evaluation

- PPS Performance Testing

- Insider threat analysis

- Configuration management

- Radiation portal monitors

Two of these workshops had significant impact on current regulation development activities. It is expected that results of other workshops will be used in the future.

A workshop to discuss PPS vulnerability analysis and effectiveness evaluation was conducted in October 2011. The goal of this workshop was to discuss differences in the U.S. and Russian approaches to PPS vulnerability analysis (VA) and effectiveness evaluation (EE) and resolve critical comments provided by the U.S. experts on the content of the draft regulations covering these issues. During the course of the workshop Russian experts delivered several presentations outlining the Russian approach to VA and EE. Based on the resulting discussion, U.S. experts acknowledged the validity of the Russian approach and a decision was made to proceed with developing regulations covering VA and EE.

Two workshops covering PPS performance testing were conducted in May 2011 and April 2012 at ISTC in Obninsk, Russia. The goal of the first workshop was to agree on a mutually acceptable understanding of the term "performance testing" and develop a definition for this term that can later be used in joint activities, including regulations development. The goal of the second workshop was to promote a broader understanding of the performance testing concept among Russian facility personnel. The workshop consisted of a mix of lectures on the issue of performance testing delivered by the U.S. and Russian experts and practical exercises aimed to demonstrate the U.S. and Russian approaches to PPS performance testing applied to a hypothetical nuclear facility developed at ISTC. As a result of this workshop, significant progress was achieved in developing an understanding of the performance testing concept among the Russian experts, definition of performance testing was agreed, and necessary regulatory development activities were identified. 
Additionally, the U.S. and Russian sides conduct continuous analysis of existing and newly enacted regulations to determine regulatory coverage of sustainability elements and key PP regulatory issues and identify regulatory gaps that need to be covered through future work. This work is implemented using a special database and analytical tool that was developed by the U.S. side and is currently being transferred for operation and maintenance to Rosatom. These activities allow the experts to prepare justified suggestions for future versions of the regulatory development plan. 


\subsection{FUTURE REGULATORY DEVELOPMENT ACTIVITIES}

Over the last year, the Russian and U.S. sides worked to discuss and agree on future regulations development activities. As a result of this work, an updated regulatory development plan was approved by both sides. This plan is based on the feedback from implementing regulations issued earlier and regulatory gaps identified as part of joint activities outlined above.

Table 3 provides a list of the most important regulations planned for development in the nearest future.

Table 3. Physical protection regulations planned for development in the near future

\begin{tabular}{|c|c|}
\hline Title & $\begin{array}{c}\text { Start of } \\
\text { Development }\end{array}$ \\
\hline Standard (Model) Form for Vulnerability Analysis Reports & 2012 \\
\hline Standard (Model) Form for Effectiveness Assessment Reports & 2012 \\
\hline $\begin{array}{c}\text { Methodological Recommendations for Performance Testing } \\
\text { Activity }\end{array}$ & 2012 \\
\hline $\begin{array}{c}\text { Instruction for Organizing the Design of Physical Protection } \\
\text { Systems }\end{array}$ & 2012 \\
\hline $\begin{array}{c}\text { Agency level document on Personnel Reliability Program } \\
\text { Standard (Model) Form for the Categorization of Objects of } \\
\text { Physical Protection and Nuclear Sites Reports }\end{array}$ & 2013 \\
\hline $\begin{array}{c}\text { Methodological Recommendations for determining the boundaries } \\
\text { of vital, inner and protected areas }\end{array}$ & 2013 \\
\hline $\begin{array}{c}\text { Methodological Recommendations on Development of model } \\
\text { Statement of Work for Technical Security Systems Creation } \\
\text { (Modernization) }\end{array}$ & 2013 \\
\hline
\end{tabular}


PNNL-21418

\subsection{SUMMARY}

Rosatom State Corporation pays significant attention to improvement of the regulatory base in the area of physical protection of nuclear sites. New regulations are developed and regulations issued earlier are revised. The U.S. DOE provides significant support in this process through the U.S.-Russian MPC\&A Program.

This paper discusses the unified regulation development procedure and progress achieved over the recent years, and outlines regulations developed and enacted by Rosatom in 2009-2011, as well as those currently under development and planned for development in the future. Additional activities supporting regulation development process are reviewed. 
PNNL-21418

\subsection{REFERENCES}

1. Convention on Physical Protection of Nuclear Materials, 1980, IAEA, INFCIRC/274 (with modifications dated 07.07.2005).

2. Physical Protection of Nuclear Materials and Facilities, 2011, IAEA, INFCIRC/225/rev.5.

3. Federal Law №170 of November 11, 1995 "On Atomic Energy Use”

4. Government Decree №456 of July 19, 2007 "Rules on Physical Protection of Nuclear Materials, Nuclear Facilities and NM Storage Points"

5. O'Brien P., Wright T, Hazel M., Izmaylov A., Babkin V., Kovchegin D. et al. Development of Regulatory Documents for Creation (Upgrade) of Physical Protection Systems under the U.S.-Russian MPC\&A Program. Proceedings of the 50 ${ }^{\text {th }}$ INMM Meeting, 2009. 